\title{
THE STRUCTURE OF FOWL-POX INCLUSIONS (BOLLINGER BODIES)
}

\author{
By G. EAVES AND T. H. FLEWETT \\ Departments of Experimental Pathology and Cancer Research, \\ and Bacteriology, Medical School, Leeds 2
}

(With Plates 4-7 and 1 Figure in the Text)

There is general agreement that the cytoplasmic eosinophilic inclusions found in cells infected with fowl-pox virus consist of aggregations of virus particles, possibly embedded in a matrix. It seemed likely that these inclusions might also be sites of virus multiplication, and therefore that electron microscopy of sections through them might afford some evidence of the way in which virus multiplication takes place.

\section{MATERIALS AND METHODS}

The strain of fowl pox was kindly sent to us from the Ministry of Agriculture and Fisheries Laboratory at Weybridge as frozen-dried infected chorioallantoic membranes. This strain was isolated in Great Britain 6 or 7 years ago, and since then has been passaged at irregular intervals through fowls and embryonated eggs. An emulsion of the frozen-dried membranes we received was inoculated on to chorioallantoic membranes of 12-day hens' eggs. After 3 days' incubation at $35^{\circ} \mathrm{C}$. the membranes were harvested and ground up in a mixture of $0.85 \%$ saline ( 3 parts) and 'Lemco' broth ( 1 part). The suspension was centrifuged at $1500 \mathrm{~g}$ for 10 min., and the supernatant was inoculated in serial ten-fold dilutions on to fresh chorioallantoic membranes of 12-day chick embryos. Eggs receiving a dose which produced three to six pocks per membrane were incubated for 5 days. The membranes of these eggs then showed large pocks, 5-6 mm. diameter, almost completely transparent, with ill-defined edges. There was no naked-eye evidence of necrosis.

$2 \%(\mathrm{w} / \mathrm{v})$ osmium tetroxide solution in $\mathrm{m} / 30$ sodium-veronal-acetic acid buffer, $\mathrm{pH} 7 \cdot 35$, was dropped on to the membranes and left for $15 \mathrm{~min}$. The membranes were then removed from the egg; pieces (about $\mathrm{I}-2 \mathrm{~mm}$. square) were cut from the centres and edges of the lesions, and fixed for a further $3 \frac{1}{2} \mathrm{hr}$. in the same fixative. They were then embedded in methacrylate, and thin sections (about $200 \AA$. thick) were cut by the method described by Eaves \& Flewett (1954). The sections were photographed in a RCA EMU $2 \mathrm{C}$ electron microscope equipped with a $200 \mu$ objective aperture.

\section{RESULTS}

Sections $1 \mu$ thick were examined by phase-contrast microscopy. Thin sections were cut from the same block for electron microscopy. It was observed by the first method, and confirmed by the second, that a great proliferation of chorionic epithelium had taken place, and that it was many cell layers thick. No sign of cell necrosis was seen, though the connective tissue of the membrane showed some fibroblastic proliferation and infiltration with macrophages. 
Nearly all the epithelial cells contained one or more cytoplasmic inclusions, around which isolated elementary bodies occurred. A few elementary bodies were also seen scattered through the cytoplasm, but the great bulk of the virus was in the form of inclusions. No virus particles were seen in epithelial nuclei or in connective tissue cells. The strain of virus behaved as described by Burnet (1936). Dense oval or spherical objects with an apparently homogeneous structure 1-3 $\mu$ in diameter, sometimes with irregular edges, are commonly found in normal chorionic cells. Some inclusions appeared to have formed around these objects. Others appeared to have formed around a vacuole; others again showed no such centre. It may be that all inclusions are formed about some previously existing structure, and that those inclusions in which no distinctive centre was seen were sliced tangentially (Pls. 4-6). Dense granular and filamentous material was always

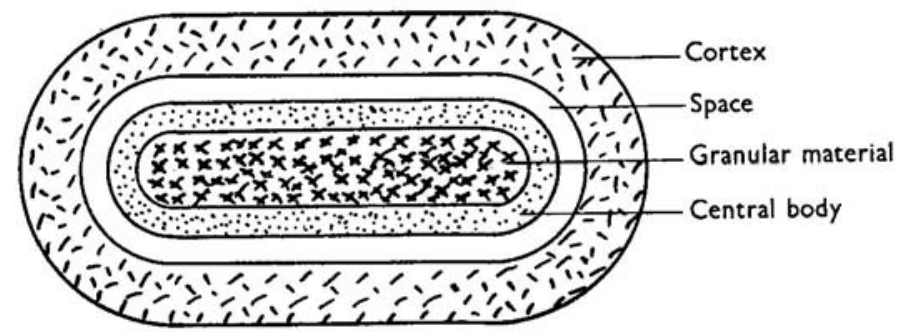

Text-fig. 1. Diagram of structure of mature virus particle.

found in the centre of inclusions, but not at their periphery. The size of the granules varied from particles less than $10 \mathrm{~m} \mu$ in diameter to filaments $20 \mathrm{~m} \mu$ wide and $300 \mathrm{~m} \mu$ long. Around the centres of these inclusions, virus elementary bodies were seen. Those near the centres were relatively poorly defined, consisting of a central oval or dumb-bell-shaped core surrounded by a single membrane, both with a granular structure similar to the free granular material which lay in the centre of the inclusion and between the inner virus particles. The outer virus particles were mostly arranged with their long axes parallel to the surface of the inclusion. They had a clearly defined structure (Pl. 7 and Text-fig. 1) consisting of an oval or dumbbell-shaped core about 100-180 $\mathrm{m} \mu$ long, with dense granular material embedded in its centre, surrounded first by a space, not dense to electrons, and then by a layer $20 \mathrm{~m} \mu$ thick, which sometimes appeared finely granular. The dimensions of the spaces were more variable than those of the other parts of the particles, and it is reasonable to suppose that they are artifacts due to the shrinking of the core during fixation or embedding. The outlines of the virus particles appeared ovoid, not rectangular as they appear when dried from aqueous suspension and shadowed.

\section{DISCUSSION}

It is tempting to postulate from these results a process of virus formation analogous to that of the sporozoa, when nuclear material divides in an undifferentiated mass of cytoplasm, and a layer of cytoplasm subsequently becomes defined around each nuclear fragment. But the very different appearances observed by Morgan, Ellison, 
Rose \& Moore (1954, and personal communication) in electron micrographs of sections of fowl-pox infected egg membranes remain to be explained. Using a technique very similar to ours, they found no cytoplasmic inclusions in fowl-pox infected cells, but found numerous virus particles consisting of a dense eccentric body surrounded by a single membrane which they regard as a developmental form of the virus. We have seen such bodies but in our material they have been very scanty.

The structure of the mature virus particles towards the periphery of the inclusions confirmed our previous observations on vaccinia virus (Flewett \& Eaves, 1954), though the detailed structure was better seen in the case of fowl-pox virus.

The work of Peters \& Stoeckenius (1954) suggested that the deoxyribonucleic acid of the virus is concentrated in the outer part of the core, or perhaps in the space around it. This work was based on the appearance in the electron microscope of whole elementary bodies which had been treated with various enzymes.

\section{SUMMARY}

The cytoplasmic inclusion bodies produced by fowl-pox virus in the chorioallantoic membrane of the egg consist of a mass of virus particles, frequently surrounding an apparently normal component of the cytoplasm. Finely granular or filamentous material is seen in the centre of the inclusion and round the more central virus particles into whose structure it appeared to be incorporated. The inner virus bodies consisted of a granular core surrounded by a single membrane. The outer virus bodies consisted of a cortical layer $20 \mathrm{~m} \mu$ thick, enclosing a space in which lay a core with a granular centre.

Acknowledgement is due to Miss Pamela Tymms for preparation of the photographic enlargements.

\section{ADDENDUM}

Since this paper was submitted for publication, Dr Rose has informed us that he and his colleagues have found virus aggregates of the type described here in cells infected with their strain of fowl-pox virus.

\section{REFERENCES}

Burnet, F. M. (1936). The cultivation of virus in the developing hens' egg. Spec. Rep. Ser. med. Res. Coun., Lond., no. 220.

Eaves, G. \& Flewetw, T. H. (1954). Exp. cell. Res. 6, 155.

Flewett, T. H. \& Eaves, G. (1954). J. Path. Bact. (in the Press).

Morgan, C., Eluison, S. A., Rose, H. M. \& Moore, D. H. (1954). J. exp. Med. 100, 301.

Peters, D. \& Stokckentus, W. (1954). Paper read at International Congress on Electron Microscopy, London. 


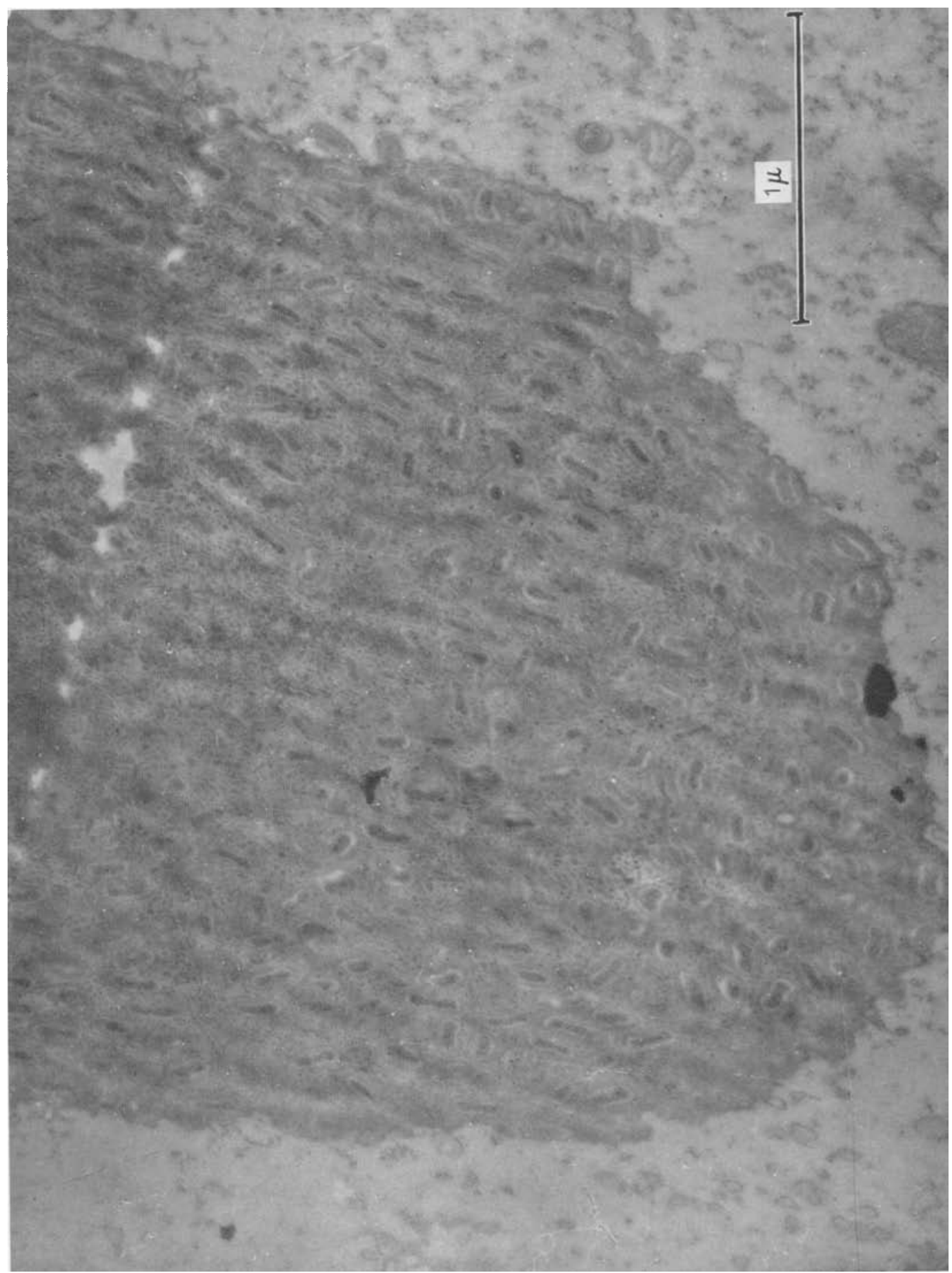

(Facingl p. 104) 


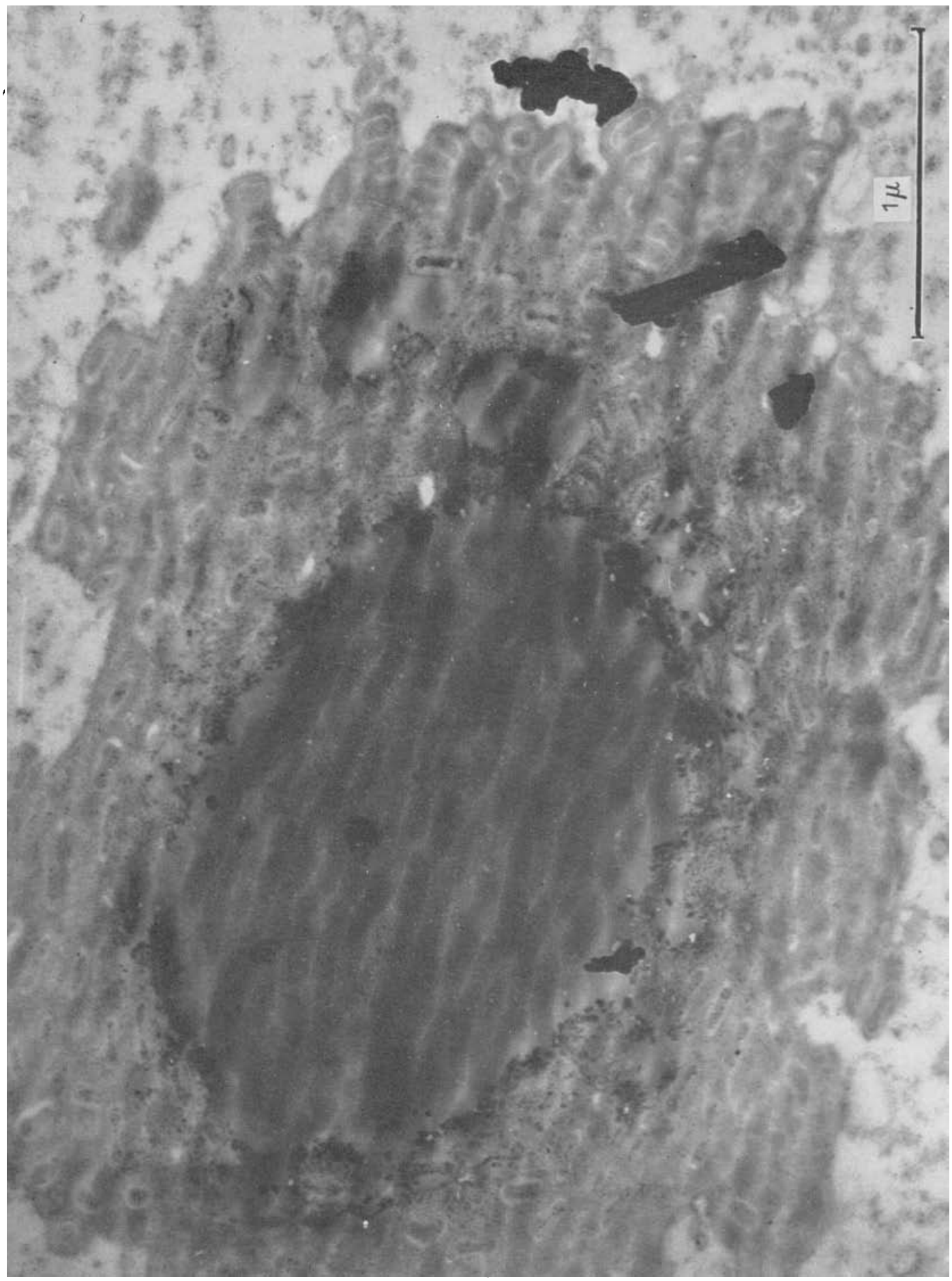




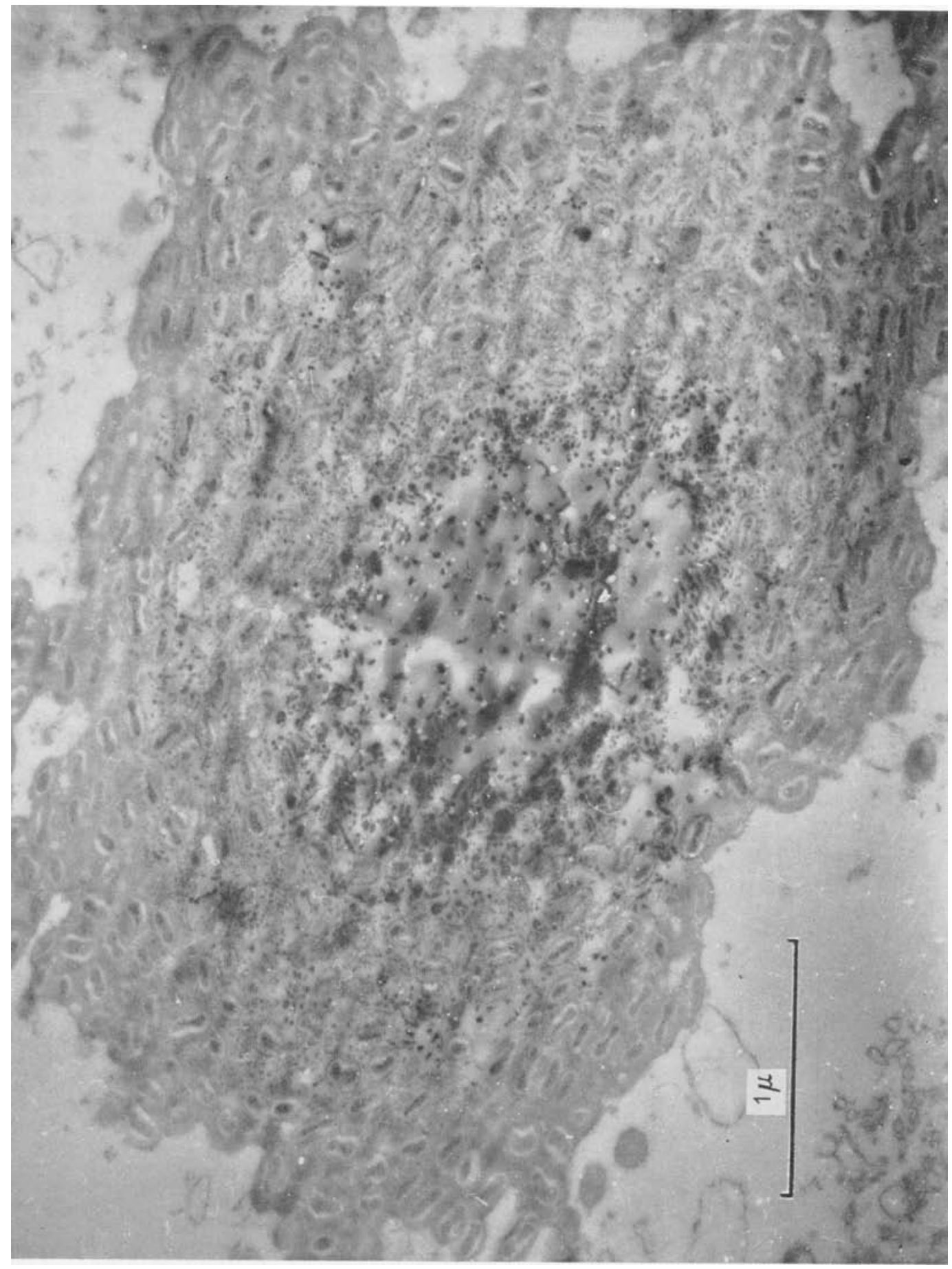



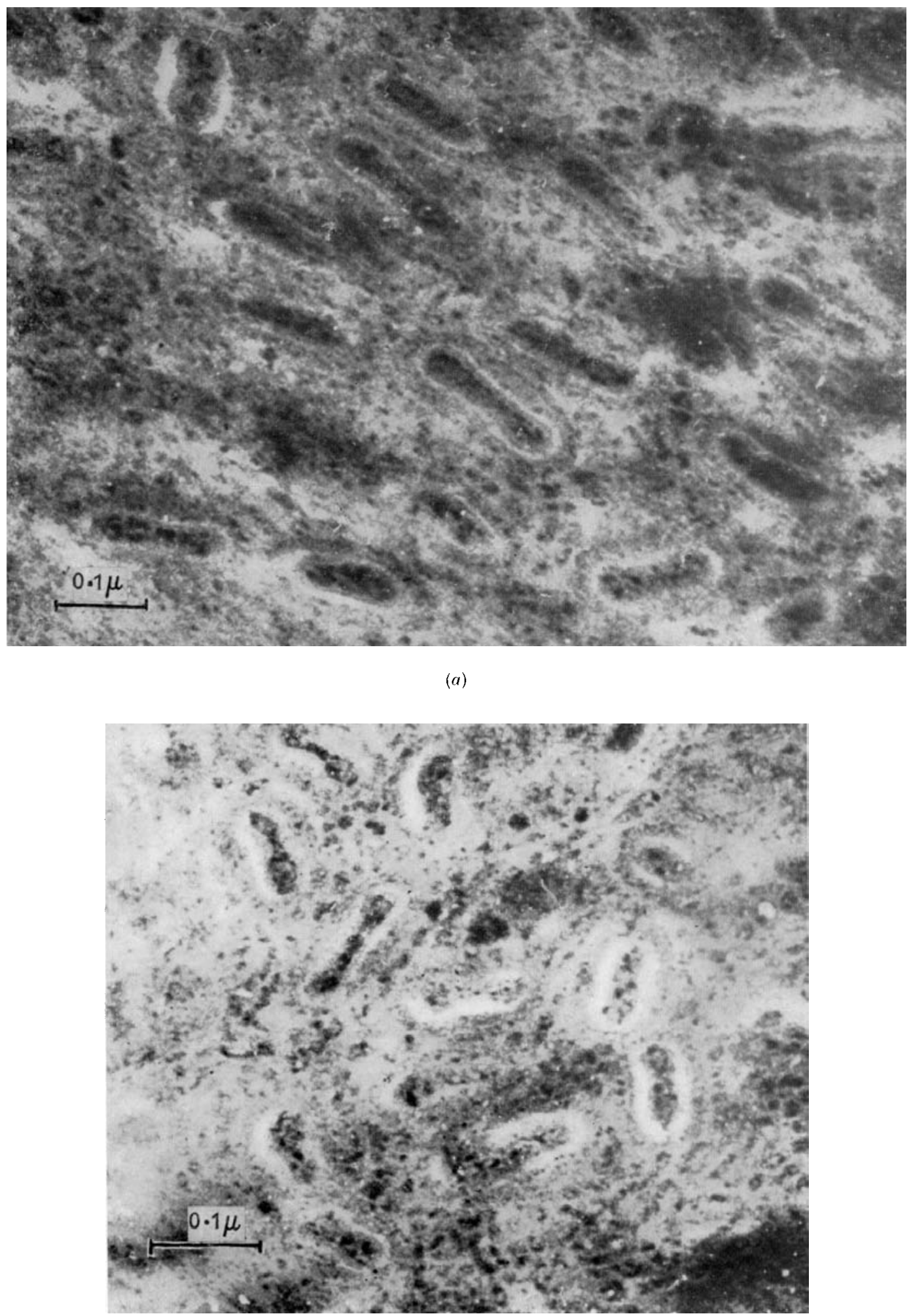

(b) 


\section{EXPLANATION OF PLATES}

\section{Plate 4}

Fowl-pox inclusion body in chorioallantoic epithelium, showing apparently solid mass of elementary bodies.

\section{Plate 5}

Fowl-pox inclusion body in chorioallantoic epithelium, showing dense central mass.

\section{Plate 6}

Fowl-pox inclusion body in chorioallantoic epithelium, showing central granular mass.

\section{Plate 7}

$a$ and $b$. Enlargements of parts of an inclusion body showing the structure of the elementary bodies. In both the direction of cut was parallel to the sides of this page. Compression distortion is seen to make no difference to the essential details of the structure.

(MS. received for publication 23. Ix. 54) 